DOI 10.37882/2500-3682.2021.02.16

\title{
ДУХОВНЫЕ ФАКТОРЫ ДЕСАКРАЛИЗАЦИИ ПРИРОДЫ В УСЛОВИЯХ СТАНОВЛЕНИЯ ИНДУСТРИАЛЬНОГО ГОРОДА
}

\section{SPIRITUAL FACTORS OF DESACRALIZATION OF NATURE IN THE CONDITIONS OF FORMATION OF AN INDUSTRIAL CITY \\ T. Maisner}

Summary: The article is devoted to the study of spiritual factors that aggravate the tendency of human alienation from nature in the context of European industrialization and urbanization. It is noted that the process of desacralization of nature is due to the formation of an anthropocentric worldview, the development of natural sciences and the industrial revolution in Europe.

Keywords: anthropocentrism, desacralization of nature, mechanistic picture of the world, utilitarianism, industrialization, urbanization.

\author{
Майснер Татьяна Николаевна \\ К.ф.н., дочент, Южно-Российский государственный \\ политехнический университет \\ (НПИ) имени М.И. Платова, г. Новочеркасск \\ designtatyana@yandex.ru
}

Аннотация: Статья посвящена исследованию духовных факторов, усугубляющих тенденцию отчуждения человека от природы в условиях европейской индустриализации и урбанизации. Отмечается, что процесс десакрализации природы обусловлен формированием антропоцентрического мировоззрения, развитием естественных наук и промышленной революцией в Европе.

Ключевые слова: антропоцентризм, десакрализация природы, механистическая картина мира, утилитаризм, индустриализация, урбанизация.

качеств, таких, как стремление к свободе, инициативность, предприимчивость, экономическая активность, творческое начало, что отчасти создало предпосылки для становления новой антропоцентрической картины мира. Последняя стала включать совершенно иную систему ценностей, чем средневековый теоцентризм, поскольку в условиях культуры Возрождения начинается процесс возвышения «ценности земного бытия человека, его стремление к творчеству, реализации деловых качеств, утверждению индивидуальности. В это время складывается система ценностей не «раба божьего», а «свободного и славного мастера» [3, с.25]. Таким образом, основным принципом антропоцентризма становится представление о человеке как творце, являющимся самодостаточной ценностью и обладающим властью над природой.

Следует отметить, что выдвижение человека на первый план происходит по двум направлениям:

- Обожествление человека, начатое в работах ранних итальянских гуманистов (Ф. Петрарка, Дж. Манетти, Л. Валла и др.). В их творчестве человек поднимается на уровень Бога и уравнивается с ним в творческих способностях. Как утверждал Дж. Монетти превосходство человека состоит в том, что Бог сотворил и его и природный мир, но человек представляет собой более совершенный и сложный мир культуры [4].

- Освобождение человека от фатализма христианского вероучения и церковного прессинга. В эпоху Возрождения, по сравнению со средневековьем, кардинально была переосмыслена про- 
блема свободы: идея божественного проведения была заменена идеей Фортуны, под которой понималась социальная необходимость. В результате, человек начинает рассматриваться как свободное существо, хозяин собственной судьбы, способный творить по собственным канонам.

Поскольку в эпоху Возрождения происходит отказ от христианского аскетизма, то в концепциях философов-гуманистов начинает возвеличиваться я не только духовные свойства человека, но и его телесное совершенство. В результате происходит реабилитация плоти (природной сущности человека), которая, в предшествующую средневековую эпоху, расценивалась как тленное начало и источник греховности. Следствием реабилитации телесности становится распространение в культуре принципа гедонизма, ориентирующего жизнь человека на получение удовольствий. Как утверждал Л. Валла, что без добродетели жить можно, а без наслаждений нельзя [5].

Появление такого рода новых идей способствовало началу процесса секуляризации общества, основным содержанием которого стала «десакрализация общественной жизни, освобождение ее из-под контроля религии и церкви... Наука, право, политика, искусство, мораль, общественная жизнь, быт людей, их сознание и поведение во всевозрастающей степени выходят из-под контроля религии» $[6$, с.196]. Это привело к девальвации теоцентризма и замещению его новой мировоззренческой матрицей - антропоцентризмом.

Рассматривая природу антропоцентризма, исследователи утверждают, что он является исключительно европейским типом мышления и мироощущения, для которого свойственно «увлечение собственными силами и возможностями, уверенность в своем всемогуществе, порождающее деятельный характер европейской культуры, активизм по отношению к миру» [7, с.162]. Эпоха Возрождения характеризуется поворотом от религиозной парадигмы к светскому признанию человека в качестве центра мироздания и его творца. Бурное развитие искусства и науки привело к вере человека в собственные силы, как в сфере творчества, так и в сфере научного познания окружающего мира.

Появление новой системы ценностей способствовало дальнейшему отчуждению человека от природы, связанного с дальнейшей ее десакрализацией, в результате которой «естественная тенденция «возделывания», облагораживания природного начала замещаться на его преобразование и прямого подавления» [8, с.18].

Надо отметить, что в научном знании сложилось несколько подходов относительно времени появление антропоцентризма, в рамках которого обосновывается высокий статус человека в мире. Некоторые авторы полагают, что антропоцентризм со своей ключевой установкой на доминирование человека над природой зародился еще до эпохи Возрождения, предпосылки к его появлению формировались как в античной философии, так и в христианском вероучении.

По мнению ряда исследователей, идея значимости человека и его главенствующее положение по отношению к миру природы обосновывается Аристотелем, в учении которого присутствует представление о иерархии человека, растений и животных, где каждый занимает отведенное ему место. Так, с точки зрения античного мыслителя, растения существуют для животных, а животные для человека. В такой системе взаимоотношений человек занимает более высокую позицию. На этом основании, американский ученый Ю. Харгроув приходит к выводу о том, что большинство неприемлемых для экологии идей зародилось еще в лоне античной философии [9].

В свою очередь, Л. Уайт утверждает, что антропоцентрическая установка на покорение природы имеет место и в христианской идеологии, где человек понимается как «образ и подобие Бога», а следовательно, представляет собой сверхприродное существо. Такая трактовка человека, по мнению ученого, лежит в основе экологического кризиса, который является следствием «ортодоксального христианского высокомерия в отношении природы» [10, р. 1205]. В силу этого христианство позволило человеку относиться к природе как творению низшего порядка, которое создано исключительно для его нужд.

Аналогичной позиции придерживается отечественный исследователь Л.И. Василенко, полагающий, что именно «разрушение языческого анимизма означало утверждение безразличия к «самочувствию» природных объектов, что открывало психологическую возможность эксплуатации природы» [11, с.156].

Надо отметить, что такой подход разделяют многие современные авторы, полагающие, что «идея господства человека над природой встречается ещё в Ветхом завете, правда, там она звучит скорее как ответственность человека перед Богом за всё, происходящее в природе. Но на протяжении столетий содержание понятия «господство над природой» постепенно трансформируется, и вместо ответственности за окружающий мир появляется тенденция перестраивать его сообразно нуждам человека» $[12$, с.14].

Данные подходы отражают истоки антропоцентризма, но все-таки в своей зрелой стадии данное мировоззрение утвердилось в эпоху Возрождения и Нового времени, что отчасти было связано с развитием науки и формированием научной картины мира. Построение 
последней было связано со стремительным развитием экспериментально-математического исследования природы.

Считается, что в основе возникновения утилитарной модели отношения человека к природе лежит антропоцентрическое мировоззрение и развитие науки. Эти процессы шли одновременно, создавая новый тип общества, в рамках которого строились и новые отношения человека к естественной среде обитания. Этот процесс во многом был связан и с научными открытиями эпохи Возрождения, и, в первую очередь, переходом от геоцентрической системы Птолемея к гелиоцентрической системе Коперника, которые расшатывали религиозную картину мира.

Большинство исследователей все-таки полагает, что именно в Новое время складывается потребительская модель отношения человека к природе, связанная с активным развитием экспериментального естествознания, которое положило начало переходу «от созерцательного, романтического отношения к природе к отношению, основанному на трезвом расчете технического использования» [1, с.310]. Причем эта тенденция свойственна представителям как эмпирического, так и рационалистического направлений.

Установка на покорение природы присутствует в рассуждениях Р. Декарта, который пишет следующее: «...можно достигнуть познаний очень полезных в жизни, и вместо той умозрительной философии, которую преподают в школе, можно найти практическую философию, при помощи которой, зная силу и действие огня, воздуха, звезд, небес и всех других окружающих нас тел также отчетливо, как мы знаем различные занятия наших ремесленников, мы могли бы точно таким же способом использовать их для всевозможных применений и тем самым сделаться хозяевами и господами природы» [13, с.305]. У Декарта природа представлена в образе машины, которая приводится в движение механическими принципами. В таком понимании она утратила свою специфику и превратилась в механическую систему, в которой даже животные рассматривались по аналогии с бездушным автоматом, лишенным чувств и не способным испытывать боль и страдания [13]. Тем самым, основой картезианской картины мира становится последовательный механицизм: принципы механики распространяются как на природу, так и на человека.

Именно эти философские идеи стали основой дальнейшего отчуждения человека от природы, которое зарождалось еще в лоне христианского вероучения, а свое логическое завершение получила в картезианстве, согласно установкам которого «принципы механики тождественны началам самой природы» [14, с. 140].
Прагматический подход к пониманию природы присутствует и в работах Дж. Локка, который утверждает, что в естественном состоянии природа не имеет ценности, поскольку главное ее назначение - это приносить пользу человеку. Английский философ выделяет два мира - природу и общество: природа представляет собой совокупность ресурсов для человечества, а общество, состоящее из автономных индивидуумов, пытается извлечь эти ресурсы для своих целей. То есть основная цель человека индустриального общества (эпохи модерна) - это достижение личного интереса и извлечение прибыли. В таком обществе природное сырье становится товаром и обретает сугубо материальную ценность. Такой утилитарный подход в отношении к природе обеспечивал научную основу для ее коммерческой эксплуатации. Более того, по мнению Дж. Локка, чем больше природных ресурсов потребляют люди, создавая предметы, обладающие товарной стоимостью, тем более автономными и счастливыми они станут. С точки зрения мыслителя, путь к счастью заключен в отрицании природы [15]. Таким образом, счастье отождествляется со свободой и успехом, в основе которых лежит процесс превращения природы в мир вещей. Основной посыл его философии заключается в том, что именно научное знание дает техническую власть над природой и это является ключевым принципом практической деятельности людей.

Как отмечают исследователи, механистическая картина мира и формирующийся утилитаристский подход к природе, утверждаемые в учении Р. Декарта и Дж. Локка «вполне подходили для того мира, где вся природа, как и люди, была низведена до количественного статуса, определяемого на основе рыночной стоимости. Новая денежная экономика свела весь мир к манипулируемому веществу, а все взаимоотношения - к количественной основе. Внутреннюю ценность сотворенного Богом заменила утилитарная ценность вещей, создаваемых людьми» [16, с.143].

Тем самым, можно заключить, что развитие антропоцентризма, науки, ориентированной на пользу человечеству, и рыночной экономики шло практически одновременно и на долгие годы определило модель отношения человека и природы. По мнению ученых, «новоевропейская цивилизация акцентировано интересуется природой как источником познания и преобразования, что должно обеспечить ей социальный прогресс» [17, с.15]. Все это свидетельствует о том, что в эпоху Нового времени человек становится одержимым идеей покорения природы, установления господства над ней путем ее научного познания и управления ее стихиями на основе рационального подхода.

Ради справедливости надо отметить, что в трудах таких мыслителей, как Ш. Монтескье, Ж.Ж. Руссо, К.А. Гельвеций, отчасти возрождаются античные установки 
в понимании взаимоотношения человека и природы, связанные с ее сакрализацией, подчеркивающие ее значимость в социальном жизни. В частности, позиция Ш. Монтескье, которая в философском знании характеризуется как географический детерминизм, заключается в том, что специфика общества обусловлена исключительно природными факторами (территорией, климатом и пр.). Тем самым, у него социальное выступает производным от той естественной средой, в которой оно развивается [18].

В учении Ж.-Ж. Руссо природа рассматривается как отражение души человека, поэтому для него высшей ценностью выступает наличие между ними согласия. Более того, по мнению мыслителя, переход человека от природного (естественного) состояния к социальному (искусственному) является источником всех несчастий человечества [19].

Дальнейшее общественное развитие, связанное с интенсификацией человеческой деятельности, процессом секуляризации и непомерным разрастанием частнособственнического эгоистического интереса способствует нарушению этого баланса в социоэкосистеме, что приводит к угрозам экологического характера. Поэтому, важно подчеркнуть, что в основе современного экологического коллапса лежит не столько сама идея господства и могущества человеческого разума над природой, сколько ее неадекватное антигуманное истолкование и применение.

Надо отметить, что уже в работах классиков марксизма присутствует предостережение относительно стихийного и необдуманного использования природы как объекта научной и производственной деятельности людей, в результате чего человек нередко оставляет после себя пустыню. Выступая против агрессивного научно-технического вторжения в природу, Ф. Энгельс предупреждает о том, что не стоит «сильно обольщаться нашими победами над природой. За каждую из таких побед она нам мстит» [20].

Анализ специфики духовной ситуации XVII - XIX вB., в контексте которой завершился процесс десакрализации природы и сложилось сугубо утилитарное отношение ней, позволяет заключить, что именно антропоцентризм, научно-технический прогресс и индустриализация стали факторами активного развития крупных промышленных городов, которое сопровождалось вытеснением природных зон, их загрязнением, что было обусловлено высокой концентрацией городского населения, динамикой промышленного производства, ростом бытовых отходов. Антропоцентризм, поставивший человека над природой, не только изменил его представления о самом себе, но и значительно снизил степень его ответственности за свою деятельность.

ЛИТЕРАТУРА

1. Вершков А.В. Антропоцентризм и современность // Актуальные проблемы гуманитарных и естественных наук. 2014. № 5-1. С.309-315.

2. Соловьев В.С. Сочинения в двух томах. Т. 2. М.: Правда, 1989.892 с.

3. Полосухин В.А., Артюхович Ю.В. Человек и природа в информационном пространстве. Опыт философского осмысления: Волгоград: Изд-во ВГтУ, 2015. 152 с.

4. Манетти Дж. 0 достоинстве и превосходстве человека. М.: РОССПЭН, 2014. 173 с.

5. Валла Л. Об истинном и ложном благе. 0 свободе воли. М.: Наука, 1989. 476 с.

6. Бубнов Ю.А., Радугина 0.А. Секуляризация как духовное явление европейской культуры // Теория и практика общественного развития. 2015. № 22. С.194-196.

7. Самохвалова В.И. Человек и мир: проблемы антропоцентризма // Философские науки. 1992. №3. С.161-167.

8. Самохвалова В.И. Человек и судьба мира. М.: Новый Век, 2000. 196 с.

9. Hargrove E. Foundations of environmental ethics, New Jersey, Prentice Hall, 1988. $229 \mathrm{p}$.

10. Lynn White Jr. The Historical Roots of Our Ecologic Crisis // Science. 10 Mar 1967. Vol. 155. P. 1203-1207.

11. Василенко Л.И., Антропоцентризм и его экологическая критика // Вопросы философии. 1983. № 6. С. 153-161.

12. Тюнина Е.М. Идея господства над природой в современных условиях // Инновации в науке и практике. Уфа: Изд-во 000 «Дендра», 2018. С.14-19.

13. Декарт Р. Избранные произведения. М.: Политиздат, 1950. 712 с.

14. Визгин В. Картезианство // Философская антропология 2020. Т. 6. № 1. С. 139-162.

15. Локк Дж. Сочинения: в 3-х т. М.: Мысль, 1985. Т. 1. 623 с.

16. Новожилова Е.О. Мировоззрение и устойчивость экосистем // Исторические, философские, политические и юридические науки, культурология и искусствоведение. Вопросы теории и практики. 2013. № 2 (28): в 2-х ч. Ч. І. С.142-145.

17. Барковская А.В. Природный мир: презумпция красоты // Лесной вестник. 2015. № 4. С.11-17.

18. Монтескье Ш. Избранные произведения. М.: Политиздат, 1955.803 с.

19. Руссо Ж.Ж. Трактаты. М.: Книга по Требованию, 2012.710 с.

20. Энгельс Ф. Роль труда в превращении обезьяны в человека [Электронный ресурc] https://www.politpros.com/library/28/259/

(с) Майснер Татьяна Николаевна (designtatyana@yandex.ru).

Журнал «Современная наука: актуальные проблемы теории и практики» 